\title{
Ifalian Standard UNI 9151 - a New Approach to the Design of Industrial Wood Packaging
}

\section{Talijanska norma UNI 9151 - novi pristup projektiranju industrijske drvene ambalaže}

\author{
Professional paper • Stručni rad \\ Received - prispjelo: 27. 10. 2016. \\ Accepted-prihvaćeno: 30. 8. 2017. \\ UDK: $630 * 834$ \\ doi:10.5552/drind.2017.1644
}

\begin{abstract}
The Italian wood packaging industry occupies a leading role in Europe and focuses its production on a collection of reference standards that describe the fundamental principles for designing industrial packaging made with lumber, plywood and OSB. The national standard framework, mainly based on UNI 9151 and UNI 10858, has been developed from the need for containers for the shipment of machines and equipment of any size, shape and weight in the global market. The main aim is to ensure maximum protection of goods and safety of operators in charge of the handling and transport of wooden packaging (boxes, crates, etc.). As for structural uses in building, the wood packaging industry adopted the concept of allowable stress design for approximately 50 years. Recently, the introduction of the limit states design according to the Eurocode 5 (EN 1995-1-1) and the availability of CE marked products have offered an opportunity to optimise the design not only of timber structures but also of some critical applications in the field of industrial packaging. In this context, a great effort has recently been dedicated to update the above mentioned national standards in order to implement them with the introduction of CE marked lumber and wood-based panels. The present paper describes the Italian standard framework for the industrial wood packaging and illustrates its evolution and new opportunities.
\end{abstract}

Keywords: allowable stress design, characteristic values, packaging design, state limit design, UNI 9151, UNI 10858.

SAŽETAK • Talijanska industrija drvene ambalaže ima vodeću ulogu u Europi i svoju proizvodnju temelji na zbirci referentnih normi kojima se uređuju temeljna načela projektiranja industrijske ambalaže izrađene od drva, furnirskih ploča i OSB-a. Nacionalni normativni okvir, uglavnom utemeljen na UNI 9151 i UNI 10858, razvijen je zbog potrebe za kontejnerima u kojima se strojevi i oprema različite veličine, oblika i težine otpremaju na svjetsko tržište. Glavni je cilj proizvođača ambalaže osigurati maksimalnu zaštitu robe i sigurnost osoba zaduženih za rukovanje drvenom ambalažom (kutijama, sanducima itd.) i za njezin transport. Kao i za konstrukcijsko drvo u graditeljstvu, tako je prije otprilike 50 godina industrija drvene ambalaže prihvatila koncept projektiranja ambalaže utemeljen na dopuštenom naprezanju. U novije se vrijeme uvodi model projektiranja prema graničnim stanjima,

\footnotetext{
${ }^{1}$ Authors are professors at University of Trento, Department of Civil, Environmental and Mechanical Engineering, Trento, Italy. ${ }^{2}$ Authors are employers of Federlegno-Arredo, Milano, Italy. ${ }^{3}$ Authors are research fellow, assistant professor and professor at University of Torino, Department of Agricultural, Forest and Food Sciences (DISAFA), Grugliasco (TO), Italy.

${ }^{1}$ Autori su profesori Sveučilišta u Trentu, Odjel građevinarstva, ekološkog inženjeringa i strojarstva, Trento, Italija. ${ }^{2}$ Autori su zaposlenici tvrtke Federlegno-Arredo, Milano, Italija. ${ }^{3}$ Authori su profesori Sveučilišta u Torinu, Odjel agronomskih i šumarskih znanosti i znanosti o hrani (DISAFA), Grugliasco (TO), Italija.
} 
sukladno normi Eurocode 5 (EN 1995-1-1), i dostupnost proizvoda s oznakom CE, što je prilika ne samo za optimizaciju projektiranja drvenih konstrukcija već i za neke kritične primjene, posebice u području industrijske ambalaže. U tom kontekstu u proteklom je razdoblju uložen veliki napor da se navedene talijanske norme ažuriraju kako bi se implementirale istodobno s uvođenjem CE oznake za drvnu piljenu građu i ploče na bazi drva. U radu se opisuje talijanski normativni okvir za industrijsku drvenu ambalažu i prezentira njegov razvoj i nove mogućnosti.

Ključne riječi: projektiranje na temelju dopuštenog naprezanja, karakteristične vrijednosti, dizajn ambalaže, projektiranje prema graničnim stanjima, UNI 9151, UNI 10858

\section{INTRODUCTION}

\section{UVOD}

Industrial wood packaging can be defined as a structural framework of members fastened together to form a rigid enclosure, which protects its content during handling, shipping and storage (Figure 1). This enclosure is usually of rectangular shape and may be sheathed with boards or wood-based panels (plywood or OSB).

In the last decades, the rapid increase in trades generated a high demand for containers for the worldwide shipment of machines and equipment of different size, shape and weight (Moncel and Chanrion, 2004). The wood packaging has always been adjustable to a variety of use conditions, being strong, rigid, light, cheap and quite easy to be realised in several sizes and shapes. Generally this type of packaging is custombuilt, with dimensions chosen to match the load and weights of the goods to be packaged.

The Italian national standard framework found its roots in the late 80s (Mainardi, 2009), inspired by the lack of handbooks on wood industrial packaging that, on the contrary, were available in the United States (Anderson and Heebink, 1964). In that period, further needs emerged related to the stability and safety of the wood package aimed at providing adequate protection of its content and meeting specific requirements (phytosanitary treatments, dangerous goods, etc.).

For these reasons, the Italian standard framework was structured in two main standards: UNI 9151 and UNI 10858 (Figure 2).

The first standard prescribes the design requirements of wood packaging without load, shape or dimensional limits, while the second provides a full description of the packing elements specifying load (up to $10,000 \mathrm{~kg}$ ) and dimensional limits (600 x 250 x $250 \mathrm{~cm})$.
In this term, UNI 10858 does not include superimposition and stacking requirements and refers to UNI 9151 for the design of the packaging base. Other requirements, such as the possibility of walking on the packaging, are optional. The UNI 10858 also takes into account the design and construction of wooden coils or saddles.

The above framework is completed by a series of other standards: UNI 10920, UNI 10986 and EN ISO 780. UNI 10920 and UNI 10986 set the rules in order to develop an audit of the process of design and construction, while EN ISO 780 is the reference for the handling instructions symbols.

More in detail, UNI 10920 specifies how to deal with industrial wood packaging design for an organization that needs to demonstrate its capability to consistently provide packaging that meets the applicable requirements. It also aims to enhance customer satisfaction through the effective application of the system, including processes for the continuous improvement and the assurance of conformity to the requirements set by statutory rules and by costumers.

UNI 10986 represents a guideline for the implementation of a structured management system. Finally, the described framework is completed by EN ISO 780 standard that regards the pictorial marking for the handling of goods.

UNI 9151 was recently implemented in order to optimize the packaging production with the introduction of the limit states design and to improve its integration with ISO 9000 family of standards. Today, this represents the most complete tool available for industrial packaging designers and enables to offer a high safety in the manufacture and handling of wood packaging.

In perspective, the use of design tools described by UNI 9151 will allow to meet the growing needs of the transport sector with more accurate and reliable
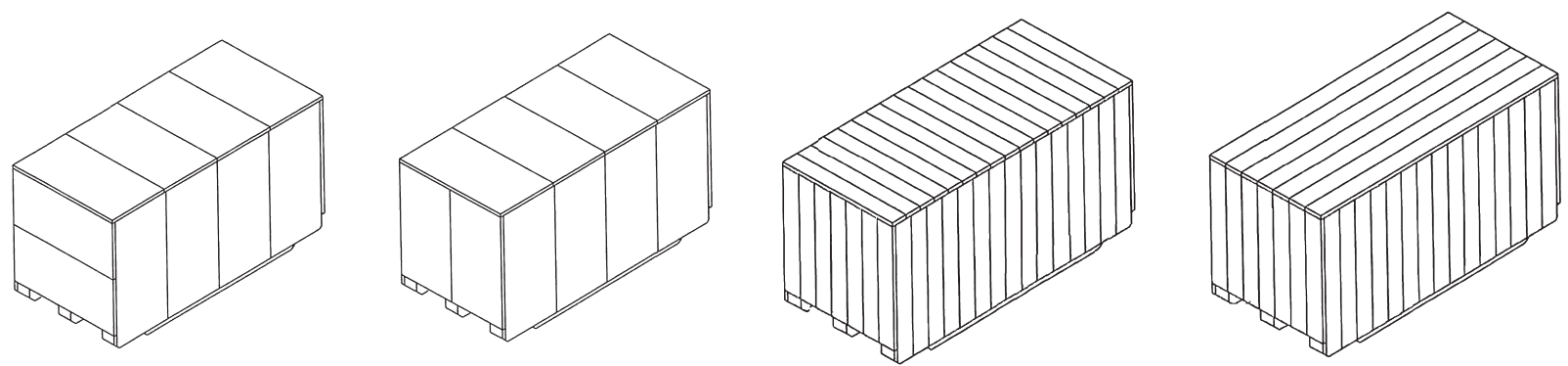

Figure 1 View of an industrial wooden box covered with plywood or OSB panels (left) or with sawn boards (right) according to the standard UNI 9151

Slika 1. Industrijska drvena kutija obložena furnirskim pločama ili OSB pločama (lijevo) odnosno piljenicama (desno) prema standardu UNI 9151 


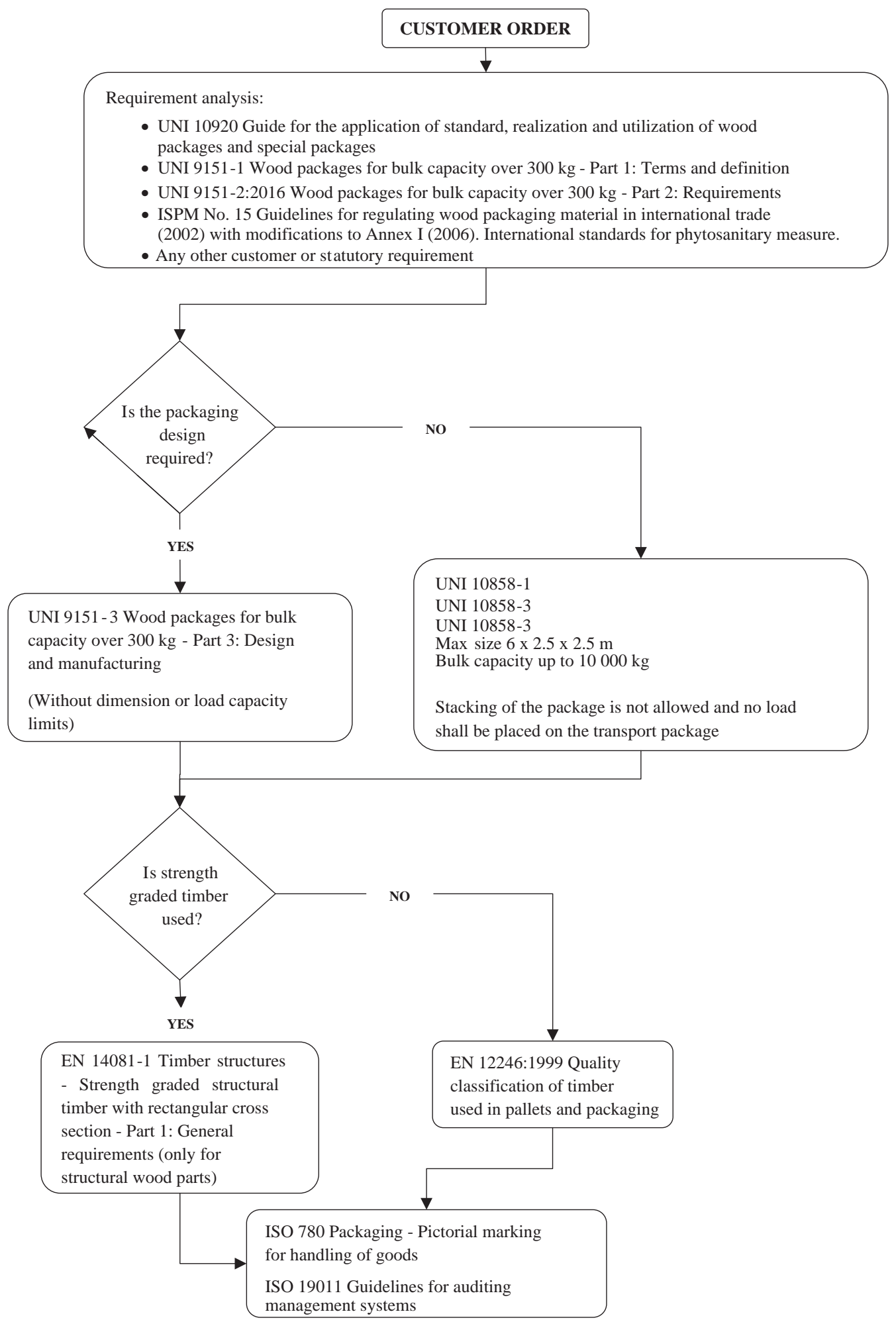

Figure 2 Scheme of Italian standardization framework for industrial wood packaging Slika 2. Shema talijanskoga normativnog okvira za industrijsku drvenu ambalažu

products through the application of specific guidelines (FEFPEB, 2006; HPE, 2014). These guidelines state that timber (boards, planks, squared battens or joists made from coniferous woods with moisture content below $20 \%$ ) shall be graded according to DIN 4074-1, specifying the quality classes to be used (S7 or S10), without providing to the operators any further information on the applicable design methods.

\section{UNI 9151 FAMILY OF STANDARDS 2. OBITELJ NORMI UNI 9151}

UNI 9151 standard was issued at the end of the 90s in order to design containers for the worldwide shipment of machines and equipment of weight over $300 \mathrm{~kg}$. Its scope was to ensure maximum protection of goods and safety of operators (Trevisani et al., 2014). The 

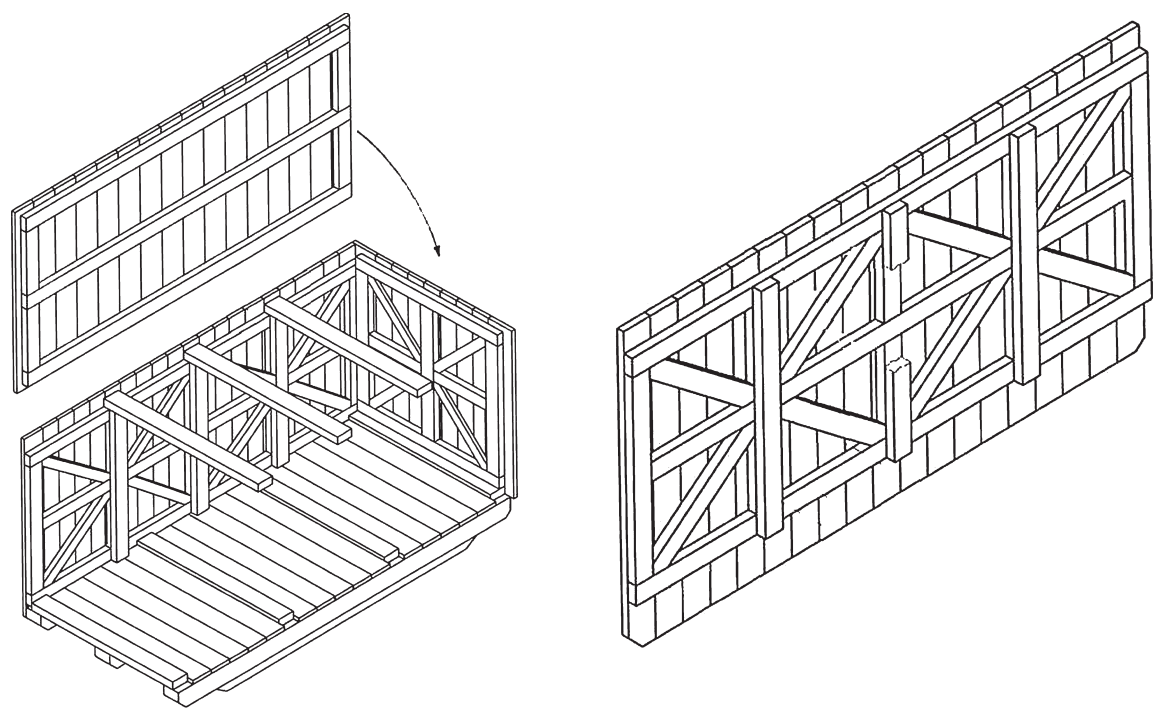

Figure 3 UNI 9151 provides details about manufacturing and assembling of wooden packages (from UNI 9151) Slika 3. Normom UNI 9151 uređuju se detalji proizvodnje i montaže drvenih paketa (iz UNI 9151)

standard structure is divided into three parts: part 1 reports terms and definitions, part 2 regards the analysis of the requirements, while part 3 , as the core section, indicates the design and manufacturing procedures.

As indicated, UNI 9151 has recently been revised not only in order to introduce the use of CE marked wood-based products but also for enhancing its integration with the standards ISO 9001 and ISO 19011. By a specific guideline (UNI 10920) and a standard for the audit process (UNI 10986), it is now possible to implement an efficient management system for wood packaging.

UNI 9151 provides a guarantee of at least 2 years but allows the producer, on the basis of contractual agreements, to cover longer periods. This goal can be obtained with an adequate design that includes a proper shape of wood packaging, an accurate distribution of the load and a correct positioning of the slinging points. In detail this means:

- perfect stability of the load, obtained by the use of necessary clamping;

- taking in due account the stresses related to the environment (handling and logistics, transport, transshipment and storage, maintenance, climatic conditions).

The security and stability of the package shall also be guaranteed in case of shocks, vibrations and roll resulting from handling, loading, unloading, stacking and transport hazards (by road, railway, sea or air).

In fact, as detailed in ISO 9001 (clause 7.3.2), each organization shall ensure that inputs related to product requirements are identified and their records maintained. In this context, UNI 9151 provides an analysis of the main requirements of the wood packaging in order to assist the organization in the design and related processes. Moreover, it establishes the requirements that can be considered essential or optional in function of the type of container.

The second part of UNI 9151 is, therefore, fundamental to identify several design inputs that shall be determined, including:

- functional, performance requirements and costs;

- statutory applicable requirements;
- information derived from previous designs;

- other requirements essential for design and development, such as ISPM No. 15 treatment (Jambreković et al. 2010).

Of course, the organization shall not only consider these inputs, but also document the implementation and ensure that they are formulated in a way that can be verified and validated. Inputs shall also be reviewed by the organization before use in order to ensure that they are adequate and that there is sufficient information to carry out the assignment. Considerations shall also be formulated to ensure that inputs are complete, unambiguous and not in conflict.

Finally, the third part of the standard provides the requirements for the design and construction of wooden containers covered with sawn boards or wood-based panels (Figure 3). The requirements are applicable to packaging produced in single units or in small series and provide design guidelines, with particular reference to minimum specific loads (stacking and superimposition) and the related accelerations for land, sea and air transport (Figure 4). In specific cases, the UNI 9151 family of standards can also be used for a weight lower or equal to $300 \mathrm{~kg}$.

This part of the standard was subjected to the most important review and updating and envisaged the introduction of CE marked wood-based materials. Unlike the Italian guidelines and specifications on the industrial packaging (Anonymous, 2006 and 2010), UNI 9151 prescribes rigorous design rules, introducing the limit states approach according to Eurocode 5 (EN 1995-1-1), but also admits the adoption of the "conventional approach" of the allowable stress design method. In this way, the standard encourages the design on limit states principles without penalizing the more traditional and established methods.

The design rules allow the use of different timber and wood-based graded materials for the construction of packages, such as:

- solid sawn timber visually graded according to EN 12246 , 

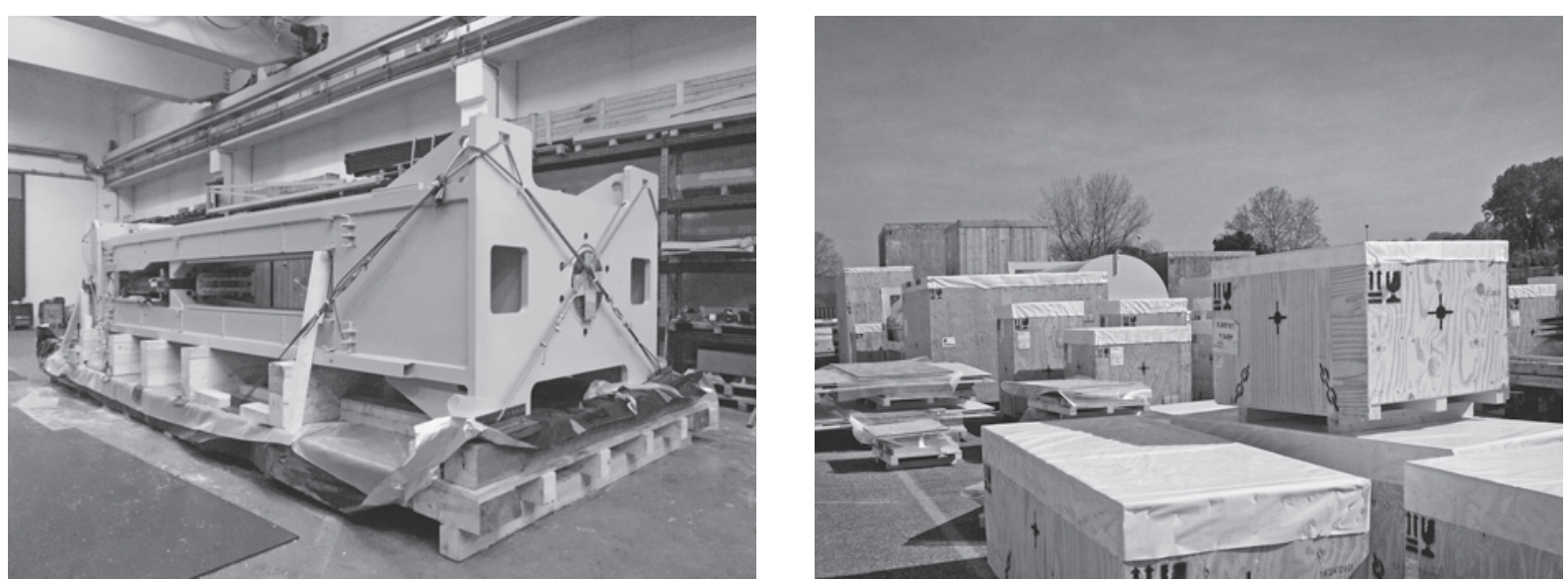

Figure 4 A heavy load industrial wood packaging (about 90 tons of payload) produced according to UNI 9151 before closing of the case (left); industrial wood packaging ready for shipment (right)

Slika 4. Industrijska drvena ambalaža za teške terete (za približno 90 tona tereta) proizvedena prema normi UNI 9151 prije zatvaranja kućišta (lijevo) i industrijska drvena ambalaža spremna za otpremu (desno)

- solid sawn timber CE marked according to EN 14081; - glulam and glued solid timber (duo/trio) CE-marked according to EN 14080;

- structural finger jointed solid timber (KVH), CEmarked according to EN 15497;

- wood-based products (plywood or OSB/3 or OSB/4, CE-marked according to EN 13986).

As mentioned above, one of the most relevant points of UNI 9151 is its double entry procedure that offers two alternatives for the design of packaging: allowable stress or limit states design, depending on the type of wooden material. When structural wood-based materials are used, in accordance with UNI 9151, the method of calculation is based on partial safety factors for the Limit State Design (LSD). This method requires to verify that, in the main design situations (e.g. transport, handling, etc.), no relevant limit state is exceeded. According to Eurocode 0 (EN 1990), for a specific load case, the design values of the effects of actions $\left(E_{d}\right)$ can be expressed as:

$$
E_{\mathrm{d}}=\sum E_{\mathrm{i}} \cdot \gamma_{\mathrm{Sd}, \mathrm{i}}
$$

Where:

$E_{\mathrm{i}}$ is the characteristic value of the effect of the i-th action;

$\gamma_{\mathrm{sd}, \mathrm{i}}$ is a partial coefficient that takes into account uncertainties in modeling the actions and their effects.

According to the Eurocode 5 (EN 1995-1-1), the design values $R_{\mathrm{d}}$ of a strength property shall be calculated as:

$$
R_{\mathrm{d}}=R_{\mathrm{k}} \cdot \frac{k_{\mathrm{mod}}}{\gamma_{\mathrm{m}}}
$$

Where:

$R_{\mathrm{k}}$ is the characteristic value of a strength property; $\gamma_{\mathrm{m}}$ is the partial safety factor for the material;

$k_{\text {mod }}$ is the modification factor that takes into account the effect of the duration of load and moisture content.

The recommended partial factors $\gamma_{\mathrm{m}}$ are, respectively, 1.30 for timber, 1.25 for glued laminated timber, 1.20 for plywood and OSB, and 1.30 for connections.
The modification factor $k_{\text {mod }}$ is defined according to EN 1995-1-1, § 3.1.4 for short-term actions and for the service class 2, with reference to a wood moisture content not greater than $20 \%$ and for the service class 3 , with reference to a wood moisture content greater than $20 \%$.

For solid timber and glue laminated timber, the $k_{\bmod }$ assumes the value of 0.9 for wood packaging exposed to moderate humid condition or 0.7 for that in heavy humid condition (e.g. maritime transports).

In this case, the characteristic value of strength properties derives from the EN 338, that sets the characteristic values of resistance, modulus of elasticity and density for each strength class. The philosophy of the standard is to promote among designers the use of the limit states approach but also to favor the use of local timber visually graded according to the national standard UNI 11035 (Negro et al., 2013).

Once the grade is assigned to the element, EN 1912 allows to establish the correspondence between the national grade and the harmonized strength class included in EN 338. In detail, EN 1912 takes into account a combination of three factors (wood species, geographical origin and national grade) to individuate the correspondent strength class of the EN 338. The system of strength classes codified by the EN 338 applies both to softwoods and hardwoods structural timber.

Since the designers of the industrial packaging sector are more familiar with the allowable stresses method, UNI 9151 gives a wide freedom of choice. Using the allowable stresses method, it shall be verified that no stress $\sigma$, calculated taking into account the effects of the actions without any safety coefficient, exceeds the allowable values $\sigma_{\mathrm{p}}$ :

$$
\sigma \leq \sigma_{\mathrm{p}}
$$

Where:

$\sigma$ is the design value of properties

$\sigma_{p}$ is the allowable stress design.

According to the standard, the values of allowable stresses $\left(\sigma_{\mathrm{p}}\right)$ can be derived, in a simplified way, from the characteristic values $f_{\mathrm{k}}$ using the following equation: 
Where:

$$
\sigma_{\mathrm{p}}=\frac{f_{\mathrm{k}}}{1.70 \cdot \gamma_{\mathrm{m}}}
$$

standard remains valid for the grading of the boards (P2) used in sheeting the sides and lid of the packaging, wooden elements that, in any case, are not taken into consideration in the context of the packing design.

In addition to the design aspects, UNI 9151, through a large number of drawings and exploded views, explains the most significant construction details, including a description of the chemical-physical properties of the protection systems.

In fact, it is well known that many construction details, as well as the design procedures, can affect the wood packaging in terms of quality and reliability.

\section{CONCLUSIONS 3. ZAKLJUČAK}

When the wood moisture content is greater than $20 \%$, the values of the admissible tensions shall be reduced by $30 \%$. When using non-structural visual graded timber according to EN 12246, the designer must calculate the packaging dimensions only with the allowable stress method (Table 2). It is important to underline that the above standard defines two timber quality classes (P1 and P2) for general uses in reusable pallets and industrial packaging. However, this standard was not specifically developed for wood packaging. In fact, EN 12246 does not admit shakes on square solid timber elements, whereas shakes are inevitably present in dry or semi-dry structural timber (P1) with large cross section used in industrial packaging. It is, therefore, clear that the presence of shrinkage shakes may become a limiting factor in the classification of wood for the industrial packing according to EN 12246. This

The Italian wood packaging industry occupies a leading role in Europe. The national standard framework (UNI 9151 and UNI 10858) was thoroughly updated in order to adapt it to the use of CE marking wood-based materials. This revision, together with the possibility of using CE marked structural timber, represents both a challenge and an opportunity for the wood packaging industry that today, as a result, can better compete with other materials on the international market.

Like other documents and guidelines, UNI 9151 gives the option of using structural graded timber, but still provides rigorous design rules aimed at using more conventional approach of the allowable stress with wood material complying with EN 14081. Actually, the national standard encourages the packaging design

Table 2 Allowable stress design values from UNI 9151-3

Tablica 2. Vrijednosti dopuštenog naprezanja pri projektiranju prema normi UNI 9151-3

\begin{tabular}{|c|c|c|c|c|c|}
\hline \multirow[b]{2}{*}{$\begin{array}{l}\text { Wood species } \\
\text { Vrsta drva }\end{array}$} & \multirow[b]{2}{*}{$\begin{array}{l}\text { Latin name } \\
\text { Latinski naziv }\end{array}$} & \multicolumn{4}{|c|}{$\begin{array}{c}\text { Allowable stress, } \mathbf{N} / \mathbf{m m}^{2} \\
\text { Dopušteno naprezanje, } \mathrm{N} / \mathrm{mm}^{2}\end{array}$} \\
\hline & & $\begin{array}{c}\text { // Compression } \\
\text { Tlačno, } \\
\text { paralelno s } \\
\text { vlakancima }\end{array}$ & $\begin{array}{c}\perp \\
\text { Compression } \\
\text { Tlačno, okomito } \\
\text { na vlakanca }\end{array}$ & $\begin{array}{l}\text { Bending } \\
\text { Savijanje }\end{array}$ & $\begin{array}{l}\text { Shear } \\
\text { Smicanje }\end{array}$ \\
\hline \multicolumn{6}{|l|}{ Softwood / Drvo četinjača } \\
\hline Norway spruce / visoka smreka & Picea abies (L.) Karst & \multirow{3}{*}{8.0} & \multirow{3}{*}{2.0} & \multirow{3}{*}{9.0} & \multirow{3}{*}{0.9} \\
\hline Silver fir / obična jela & Abies alba Mill. & & & & \\
\hline Douglas fir / obična duglazija & $\begin{array}{l}\text { Pseudotsuga menziesii (Mirb.) } \\
\text { Franco }\end{array}$ & & & & \\
\hline European larch / europski ariš & Larix decidua Mill. & 10.0 & 2.2 & 11.0 & 1.0 \\
\hline Scots pine / obični bor & Pinus sylvestris L. & \multirow{4}{*}{9.0} & \multirow{4}{*}{2.0} & \multirow{4}{*}{10.0} & \multirow{4}{*}{0.9} \\
\hline Austrian pine / austrijski bor & Pinus nigra Arnold subsp. nigra & & & & \\
\hline Corsica pine / korzikanski bor & $\begin{array}{l}\text { Pinus nigra Arnold subsp. } \\
\text { laricio (Poir.) Maire }\end{array}$ & & & & \\
\hline Maritime pine / primorski bor & Pinus pinaster Ait. & & & & \\
\hline \multicolumn{6}{|l|}{ Hardwood / Drvo listača } \\
\hline Sweet chestnut / pitomi kesten & Castanea sativa Mill. & \multirow{4}{*}{9.0} & \multirow{4}{*}{2.0} & \multirow{4}{*}{10.0} & \multirow{4}{*}{0.7} \\
\hline European ash / bijeli jasen & Fraxinus excelsior L. & & & & \\
\hline Elm / brijest & Ulmus spp. & & & & \\
\hline Eucalyptus / eukaliptus & Eucalyptus spp & & & & \\
\hline Poplar / topola & Populus spp. & 8.0 & 1.5 & 8.5 & 0.5 \\
\hline Oak / hrast & Quercus spp. & \multirow{2}{*}{10.0} & \multirow{2}{*}{2.5} & \multirow{2}{*}{11.0} & \multirow{2}{*}{1.0} \\
\hline Beech / bukva & Fagus sylvatica L. & & & & \\
\hline Robinia / obični bagrem & Robinia pseudoacacia L. & 10.0 & 2.5 & 11.5 & 1.0 \\
\hline
\end{tabular}


with graded timber without penalizing the more traditional and consolidated visual grading method described in EN 12246.

In conclusion, the UNI 9151 family of standards is a complete tool for industrial packaging designers and it can offer greater safety for the manufacturing of large packaging. In perspective, the use of this standard will allow the sector to meet the growing needs of the industrial goods logistics with a more accurate and reliable design, implemented by the application of modern practices. Considering that today there is no European standard specifically intended for industrial wood packaging sector, UNI 9151 could represent a solid starting point for developing it.

\section{REFERENCES}

\section{LITERATURA}

1. Anderson, L. O.; Heebink, T. B., 1964: Wood crate design manual. Agriculture handbook no. 252, Washington, D. C.: Forest Service U.S. Department of Agriculture.

2. Jambreković, V.; Despot, R.; Hasan, M., 2010: The overview and evaluation of phytosanitary system in companies authorised for the treatment and marking of wooden material for packaging in international trade (in Croatian). J. For. Soc. Croatia, 134 (3-4): 125-143.

3. Mainardi, G., 2009: Industrial wood packaging guidelines. Milano, Italy: ConLegno.

4. Moncel, D.; Chanrion, P., 2004: Wood packaging materials. Modernity and responsiveness to highly competitive markets (in French). Revue Forestière Française Numéro spécial: 73-80.

5. Negro, F.; Cremonini, C.; Zanuttini, R., 2013: CE Marking of Structural Timber: the European Standardization Framework and its Effects on Italian Manufacturers. Drvna industrija, 64 (1): 55-62.

https://doi.org/10.5552/drind.2013.1214.

6. Trevisani, A.; Laccheri, E.; Fabbri, A.; Guarnieri, A., 2014: Pallet standards in agrifood sector: a brief survey. J. of Agric. Engin., 220: 90-95. https://doi.org/10.4081/jae.2014.220.

7. *** 2006: Common Basic Rules in Export Packing. Paris, France: FEFPEB - European Federation of Wooden Pallet and Packaging Manufacturers.

8. *** 2014: HPE Packaging guidelines. $3^{\text {nd }}$ revised edition. Bonn, Germany: HPE - German Federal Association for Wooden packaging, Pallets, Export packaging.

9. *** EN 12246, 1999: Quality classification of timber used in pallets and packaging.

10. *** EN 14080, 2013: Timber structures - Glued laminated timber and glued solid timber - Requirements.

11. *** EN 14081-1, 2005 + A1, 2011: Timber structures Strength graded structural timber with rectangular cross section - Part 1: General requirements.
12. *** EN 15497, 2014: Structural finger jointed solid timber - Performance requirements and minimum production requirements.

13. *** EN 1912, 2012: Structural timber - Strength classes - Assignment of visual grades and species.

14. *** EN 1990, 2002: Eurocode - Basis of structural design.

15. *** EN 1995-1-1, 2004 + A2, 2014 Eurocode 5: Design of timber structures. Part 1-1: General - Common rules and rules for buildings.

16. *** ISO 19011, 2015: Guidelines for auditing management systems.

17. *** ISO 780, 1997: Packaging - Pictorial marking for handling of goods.

18. *** ISO 9001, 2015: Quality management system. Requirements.

19. *** ISPM No. 15, 2006: Guidelines for regulating wood packaging material in international trade with modifications to Annex I: International standards for phytosanitary measure. FAO, Rome, Italy.

20. *** UNI 10858 part 1, 2000: Special wood packages for bulk capacity up to $10000 \mathrm{~kg}$ and maximum size of (600 x 250 x 250) $\mathrm{cm}$ and supporting operative packages Terms, definitions and requirements.

21. ${ }^{* * *}$ UNI 10858 part 2, 2000: Special wood packages for bulk capacity between $300 \mathrm{~kg}$ and $10000 \mathrm{~kg}$ and maximum size of (600 x 250 x 250) cm Types and constructive elements, classification and manufacturing.

22. *** UNI 10858 part 3, 2000: Special wood packages for bulk capacity less than $300 \mathrm{~kg}$ and maximum size of (200x $100 \times 100) \mathrm{cm}$. Types and constructive elements classification and manufacturing.

23. *** UNI 11035-1, 2010: Legno strutturale - Classificazione a vista dei legnami secondo la resistenza meccanica - Parte 1: Terminologia e misurazione delle caratteristiche.

24. *** UNI 9151-1, 2016: Wood packages for bulk capacity over $300 \mathrm{~kg}$ - Part 1: Terms and definitions.

25. *** UNI 9151-2, 2016: Wood packages for bulk capacity over $300 \mathrm{~kg}$ - Part 2: Requirements.

26. *** UNI 9151-3, 2016: Wood packages for bulk capacity over $300 \mathrm{~kg}$ - Part 3: Design and manufacturing.

27. *** UNI 10920, 2014: Guide for the application of standard, realization and utilization of wood packages and special packages.

\section{Corresponding address:}

Dr. FRANCESCO NEGRO, Ph. D.

University of Torino

Department of Agricultural, Forest and Food Sciences (DISAFA)

Largo Paolo Braccini 2

10095 Grugliasco, ITALY

e-mail: francesco.negro@unito.it 